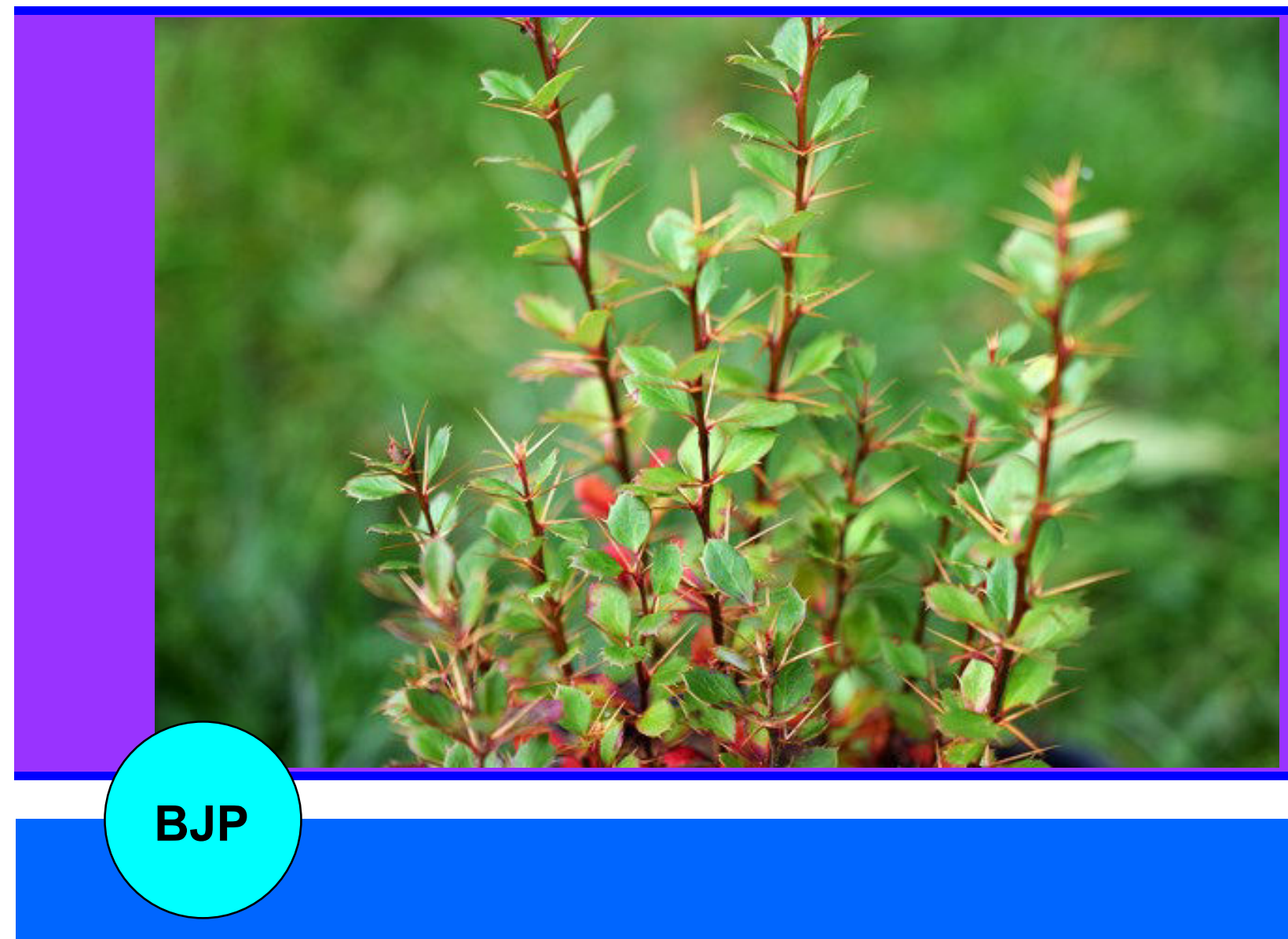

Bangladesh Journal of Pharmacology

Research Article

Antimicrobial properties of extracts and compounds isolated from Berberis jaeschkeana 
g) and basic fraction was obtained with EtOAc after basification with ammonia and it was termed as fraction C (93 g). While the left over aqueous fraction after the separation of fractions A, B and C was termed as fraction D.

\section{Phytochemical screening}

Phytochemical tests were carried out for crude ethanolic extract, fraction A, B and C to identify the chemical constituents (Edeoga et al., 2005; Uddin et al., 2012).

\section{Alkaloids}

$0.2 \mathrm{~g}$ of crude ethanolic extract and each fraction were warmed with $2 \% \mathrm{H}_{2} \mathrm{SO}_{4}$ for $2 \mathrm{~min}$. After filtration of the reaction mixture a few drops of Dragendroff's reagent were added to each filtrated fraction. Orange red precipitate indicates the presence of alkaloids.

\section{Glycosides}

Ethanolic extract and each fraction was first acidified with dilute $\mathrm{HCl}$ and then neutralized with $\mathrm{NaOH}$ solution. Now a few drops of Fehling's solution A and $\mathrm{B}$ were added to each mixture. Formation of red precipitate indicates the presence of glycosides.

\section{Flavonoids}

Five milliliters of dilute ammonia solution was added to the aqueous filtered solution of each fraction followed by the addition of conc. $\mathrm{H}_{2} \mathrm{SO}_{4}$. The appearance of yellow color indicated the presence of flavonoids. The yellow color disappeared after some time.

\section{Steroids}

Two $\mathrm{mL}$ of acetic anhydride was added to $0.5 \mathrm{~g}$ ethanolic extract of each fraction followed by adding $2 \mathrm{~mL}$ $\mathrm{H}_{2} \mathrm{SO}_{4}$. The color changed from violet to blue or green indicated the presence of steroids.

\section{Saponins}

About $2 \mathrm{~g}$ of the powdered sample was boiled in $20 \mathrm{~mL}$ of distilled water in a water bath and filtered. $10 \mathrm{~mL}$ of the filtrate was mixed with $5 \mathrm{~mL}$ of distilled water and shaken vigorously. The appearance of frothing indicated the presence of saponins.

\section{Reducing sugars}

Each sample was shaken with distilled water first and then filtered. To each filtrate a few drops of Fehling's solution A and B were added and boiled for few minutes. The appearance of an orange red precipitate confirmed the presence of reducing sugars.

\section{Terpenoids}

About $0.2 \mathrm{~g}$ of the each sample was mixed with $2 \mathrm{~mL}$ of chloroform first and then $3 \mathrm{~mL}$ of concentrated $\mathrm{H}_{2} \mathrm{SO}_{4}$ was added to each mixture. The formation of a reddish brown coloration at the interface indicated the presence of terpenoids.

\section{Microbial culture preparation}

Five strains of bacteria namely Staphylococcus aureus, Escherichia coli, Klebsiella pneumoniae, Bacillus subtilis and Staphylococcus epidermidis were used for the antimicrobial activity. The bacterial strains were collected from stock culture of Phytopharmaceutical and Neutraceutical research laboratories (PNRL), Institute of Chemical Sciences, University of Peshawar Pakistan. These organisms were placed in Muller-Hinton agar in the refrigerator at $4^{\circ} \mathrm{C}$ prior to subculture.

Anti-microbial activity of the various extracts and pure compounds against selected bacterial species

Modified agar-well diffusion method was used to test the anti-bacterial properties of the crude extract, fractions and pure compounds. Muller-Hinton agar was used as medium. The cultures were taken in triplicates at incubation temperature of $37^{\circ} \mathrm{C}$ for 24 to 72 hours. The broth culture $(0.6 \mathrm{~mL})$ of the test organism was placed in a sterile Petri-dish and $20 \mathrm{~mL}$ of the sterile molten MHA was added. Holes were bored in the medium using $0.2 \mathrm{~mL}$ of the extract, fractions and pure compounds. Streptomycin was used as standard antimicrobial agent at a concentration of $2 \mathrm{mg} / \mathrm{mL}$. Inoculation was done for 1 hour. Incubation was done at $37^{\circ} \mathrm{C}$ for 24 hours and the diameters of the zone of inhibition of microbial growth were measured in $\mathrm{mm}$.

\section{Results and Discussion}

The crude ethanolic extract of B. jaeschkeana was evaluated for its antimicrobial potential. Upon positive results the crude extract was fractionated into acidic and basic fractions according to the fractionation scheme for alkaloids. Then each fraction was evaluated for its antibacterial properties which also showed positive results (Table I; Table II). Five known compounds namely berberine (Lenka et al., 2007), columbamine (Tian et al., 2004), syringic acid (Sheng-Ming et al., 2006), berberine chloroform (Radek et al., 2003) and jatrorrhizine (Trinh, et al., 2006) were isolated from different fractions of $B$. jaeschkeana (Table III). The structures were confirmed by com-paring $1 \mathrm{D}$ and 2D NMR data of all the five compounds with the literature.

\section{Acknowledgment}

We are sincerely grateful to the Higher Education Commission of Pakistan for supporting and funding our research work and studies.

\section{References}

Edeoga HO, Okwu DE, Mbaebie BO. Phytochemical consti- 
Table I

\section{Results of preliminary screening}

\begin{tabular}{|lcccc|}
\hline Class of compound & Crude extract (ethanol) & B. jaeschkeana-A & B. jaeschkeana-B & B. jaeschkeana-C \\
\hline Alkaloids & Present & Present & - & Present \\
Glycosides & Present & - & Present & Present \\
Flavonoids & Present & - & Present & Present \\
Steriods & Present & - & Present & - \\
Saponins & Present & - & - & Present \\
Reducing sugars & Present & - & Present & - \\
Terpenoids & Present & - & Present & - \\
\hline
\end{tabular}

Table II

\section{Antimicrobial results for crude and fractions}

\begin{tabular}{|lcccccc|}
\hline Sample & $\begin{array}{c}\text { Staphylococcus } \\
\text { aureus }\end{array}$ & $\begin{array}{c}\text { Escherichia } \\
\text { coli }\end{array}$ & $\begin{array}{c}\text { Staphylococcus } \\
\text { epidermidis }\end{array}$ & $\begin{array}{c}\text { Klebsiella } \\
\text { pneumoniae }\end{array}$ & $\begin{array}{c}\text { Bacillus } \\
\text { subtilis }\end{array}$ & $\begin{array}{c}\text { Streptomy- } \\
\text { cin }\end{array}$ \\
\hline Crude ethanol extract & 14 & 12 & 16 & 14 & 16 & 30 \\
RBJ- A & 16 & 18 & 18 & 16 & 18 & 28 \\
RBJ- B & 14 & 14 & 16 & 14 & 16 & 30 \\
RBJ- C & 16 & 18 & 16 & 14 & 18 & 28 \\
RBJ-A = Acidic fraction; RBJ-B = Dichloromethane fraction; RBJ-C = Basic fraction of B. jaeschkeana & & & \\
\hline
\end{tabular}

\section{Table III}

\section{Antimicrobial results for pure compounds}

\begin{tabular}{|c|c|c|c|c|c|c|}
\hline Sample & $\begin{array}{c}\text { Staphylococcus } \\
\text { aureus }\end{array}$ & $\begin{array}{c}\text { Escherichia } \\
\text { coli }\end{array}$ & $\begin{array}{c}\text { Staphylococcus } \\
\text { epidermidis }\end{array}$ & $\begin{array}{c}\text { Klebsiella } \\
\text { pneumoniae }\end{array}$ & $\begin{array}{l}\text { Bacillus } \\
\text { subtilis }\end{array}$ & $\begin{array}{l}\text { Strepto- } \\
\text { mycin }\end{array}$ \\
\hline Berberine & 14 & 16 & 18 & 18 & 20 & 26 \\
\hline Columbamine & 20 & 18 & 14 & 22 & 20 & 28 \\
\hline Syringic acid & 20 & 18 & 16 & 20 & 18 & 28 \\
\hline Berbreine chloroform & 16 & 20 & 18 & 14 & 18 & 28 \\
\hline Jatrorrhizine & 16 & 20 & 18 & 12 & 20 & 26 \\
\hline
\end{tabular}

tuents of some Nigerian medicinal plants. Afr J Biotechnol. 2005; 4: 685-88.

Hill AF. Economic botany: A textbook of useful plants and plant products. 2nd ed. New York, McGraw-Hill Book Company Inc, 1952.

Jafri SMH. Flora of West Pakistan. Nasir E, Ali SI (eds). Vol. 87. Berberidaceae, 1975, pp 1-36.

Lenka G, Jiri D, Radek M. Quaternary protoberberine alkaloids. Phytochemistry 2007; 68: 150-75.

Mohsen I, Hossein H. Pharmacological and therapeutic effects of Berberis vulgaris and its active constituent, berberine. Phytother Res. 2008; 22: 999-1012.

Radek M, Pavlina S, Dagmar H, Jaromir M, Jiri D, Vladimir S. Palmatine and berberine isolation artifacts. J Nat Prod. 2003; 66: $481-86$.
Rashmi A, Rajasekaran, Jagdish P. The genus Berberis Linn.: A Review. Phcog Rev. 2008; 2: 369-85.

Sheng MP, Hsiou YD, Wen LC, Hang CL. Phenols from the aerial parts of Leonurus sibiricus. Chinese Pharmaceut J. 2006; 58: 35-40.

Tian JH, Yi CC, Yang CW, Chung YC. Chemical constituents from the stems of Mahonia japonica. J Chinese Chem Soc. 2004; 51: 443-46.

Trinh TT, Franke K, Porzel A, Wessjohann L, Tran VS. Quaternary protoberberine alkaloids from Stephania rotunda. J Chem. 2006; 44: 259-64.

Uddin G, Khan AA, Alamzeb M, Ali S, Rashid M, Sadat A, Alam M, Rauf A, Ullah W. Biological screening of ethyl acetate extract of Hedera nepalensis stem. Afr J Pharm Pharmacol. 2012; 6: 2934-37. 